\title{
Green and Synthetic Metallic Nanoparticles - Obtaining, Characterization and Biological Evaluation in Association with Lupeol
}

\author{
FLAVIA BOCIORT ${ }^{1 \#}$, CARMEN NICOLETA CRISAN ${ }^{2 \#}$, RAZVAN DRAGOI ${ }^{*}$, \\ ALINA HEGHES ${ }^{3 *}$, CAMELIA SZUHANEK ${ }^{4}$, MATILDA RADULESCU ${ }^{1}$, \\ DELIA BERCEANU-VADUVA ${ }^{1}$, ALINA TISCHER ${ }^{1}$, ANDREI MOTOC ${ }^{1}$ \\ ${ }^{1}$ Victor Babes University of Medicine and Pharmacy Timisoara, Faculty of Medicine, 2 Eftimie Murgu Sq., 300041, \\ Timisoara, Romania \\ ${ }^{2}$ Vasile Goldis Western University of Arad, Faculty of Medicine, 86 Liviu Rebreanu, 310045, Arad, Romania \\ ${ }^{3}$ Victor Babes University of Medicine and Pharmacy Timisoara, Faculty of Pharmacy, 2 Eftimie Murgu Sq., 300041, \\ Timisoara, Romania \\ ${ }^{4}$ Victor Babes University of Medicine and Pharmacy Timisoara, Faculty of Dental Medicine, 2 Eftimie Murgu Sq., 300041, \\ Timisoara, Romania
}

\begin{abstract}
The field of metal nanotechnology continues to draw the attention of researchers from different areas due to the outstanding properties of nanoparticles. The main aims of this research were to obtain and to study two types of gold nanoparticles; different obtaining pathways (the chemical synthesis and the biosynthesis based on an aqueous extract of lemon balm) were involved in this research. The chemically synthesized nanoparticles were loaded with lupeol. After a preliminary physico-chemical characterization, the compounds obtained were tested in order to evaluate the effects on the viability of colon cancer cells. The formulation of these new gold nanoparticles with average size between 38 and $82 \mathrm{~nm}$, with a good stability against the tendency to form agglomerations according to the Zeta potential values, was confirmed by $U V$-Vis spectra; the particles containing lupeol have show the best activity against the colon cancer cells.
\end{abstract}

Keywords: gold nanoparticles, lemon balm, lupeol, colon cancer cell

\section{Introduction}

The emergence and development of malignancy is a dynamic process that takes time, involving a number of complex factors with a different rate of progression, resulting in an uncontrolled spread and an increase in the number of cancer cells throughout the body [1]. Many studies highlight that a proper diet strategy can help prevent more than two-thirds of human cancers [2]. Interdisciplinary research is essential and requires the involvement of various specialists to find the right structure and to understand the molecular mechanisms involved in chemoprevention [1,2]. Plants are a rich source of compounds with very diverse chemical structures, which are continuously explored worldwide in the pharmaceutical field related to the discovery of drugs [3]. Functional components profile plays an important role in establishing the specific properties of every part of plant; as far as cancer therapy is concerned, the studies on plants have led to remarkable successes taking into account that over half of the approved medicines discovered in the last 20 years are of natural origin [4]. Examples of drugs approved in therapy, derived from nature and having an important role in the treatment of cancer are: vincristine, irinotecan, etoposide and paclitaxel [5].

Terpenoids present practical applications in various fields such as food, pharmaceuticals and cosmetics industries [4]. An increased interest is noted for natural triterpenoids (phytosterols) due to the wide range of biological activities. This class contains a large number of compounds that are important plant constituents [6]. Lupeol (Figure 1), a triterpene present in fruits (mangoes, olives, 
strawberries, grapes, Figures etc.), vegetables and plants (Streblus asper, Alhagi maurorum, Ulmus campestris) exerts a significant biological activity and is used to prevent and treat various diseases [69].

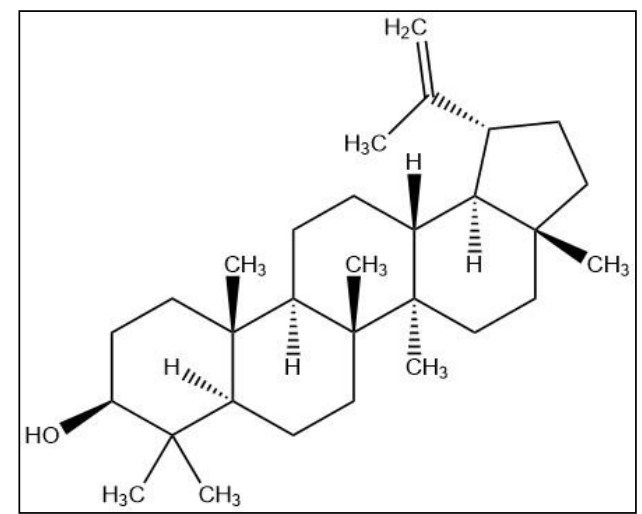

Figure 1. Chemical structure of lupeol.

Drug delivery systems, novel and innovative drug formulations, are nano- and/or micro-particles that can protect the encapsulated amount and modify its properties (log P, bioavailability, pharmaceutical efficacy etc.) [10,11]. Metallic nanoparticles have captured the attention of biomedical research due to the fact that they exert certain optical, thermal, magnetic and / or electrical properties [12]. In parallel with the study of stem cells that are present in most tissues and show the ability to regenerate, but also to generate different types of tissues [13], the understanding of the mechanisms of action and of the toxic ones between the nano-compounds and the biological environment is deepened. Thus, it is necessary to fully elucidate these interactions in order to properly synthesize nanoparticles for diagnostic and therapeutic purposes.

Gold nanoparticles have smaller dimensions than biological targets and have a specific mechanism for interacting with biomolecules and are therefore ideal for the transport of active substances to the target site, and for the imaging of diseases in a given location, an early stage [14].

The aim of the present study is to synthesize and to assess different types of gold nanoparticles: empty gold chemical colloids (AuNPs), lupeol-based gold colloids (Lup_AuNPs), and gold biochemical colloids (B_AuNPs); the colorectal adenocarcinoma cell lines HT-29 and Caco-2 were used to investigate their efficacy.

\section{Materials and methods}

\subsection{The raw materials}

All the reagents and solvents used were purchased from the specialized companies as follows: chloroauric acid, trisodium citrate, lupeol, and methanol from Sigma Aldrich (Germany). Deionized water was obtained with an Ultrapure, Millipore R Direct-Q R 3 device.

\subsection{The chemical synthesis}

The first synthesis of AuNPs was realized as previously described Turkevich [15] with minor changes: deionized water was boiling under stirring, $4 \%$ chloroauric acid solution and trisodium citrate solution were added and the reaction mixture was kept at boiling temperature for $15 \mathrm{~min}$. The solution was cooled at room temperature, purified by centrifugation in order to obtain empty gold colloids (AuNPs) and stored at $2-6{ }^{\circ} \mathrm{C}$ until further determinations. To obtain lupeol-based gold nanoparticles, a methanolic solution of lupeol $(1 \mathrm{mg} / \mathrm{mL})$ was added to a methanolic solution of AuNPs, previously obtained, at room temperature under stirring. The final solution was subjected to 
evaporation in order to remove the solvent and the nanoparticles (Lup_AuNPs) were characterized and tested.

\subsection{The biochemical synthesis}

The second synthesis of AuNPs was carried out with an aqueous extract of lemon balm: $20 \mathrm{~mL}$ extract were mixed with $20 \mathrm{~mL}$ chloroauric acid solution $(1 \mathrm{mM})$ and kept in an orbital shaker, at room temperature at $250 \mathrm{rpm}$ for $24 \mathrm{~h}$ in order to obtain B_AuNPs. The aqueous lemon balm leaves extract (LBE) was obtained by boiling $5 \mathrm{~g}$ vegetal dry material with $50 \mathrm{~mL}$ distilled water for $10 \mathrm{~min}$, cooled, filtered, and stored at $-20^{\circ} \mathrm{C}$ until further use.

\subsection{The characterization of samples}

The formation of AuNPs was monitored spectrophotometrically, by using a UV-Vis spectrophotometer (Specord 205; Analytik Jena AG, Jena, Germany) in the wavelength range 500$600 \mathrm{~nm}$.

Gold determination was conducted on a XSeries 2 ICP-MS coupled to a Cetac ASX-520 autosampler (Thermo Fisher Scientific, United States); acquisition parameters - $100 \mathrm{~ms}$ for 106Au and $50 \mathrm{~ms}$ for 193Ir (dwell time), 0.02 (separation AMU), 50 (number of sweeps), and $7 \mathrm{sec}$ (acquisition time). The standard reagents were hydrochloric acid and L-Cysteine purchased from Sigma Aldrich (Germany). Particle Size and Zeta Potential Analysis were selected to establish the particles size and their stability against the tendency to form clusters. Two different modules, Vasco Particle Size Analyzer and Wallis Zeta-potential Analyzer (Cordouan Technologies, France) with the following input parameters have been used in the characterization of samples: determination temperature $\left(25^{\circ} \mathrm{C}\right)$, time interval (around $14 \mu \mathrm{s}$ ), number of channels ( 440), power of laser (75-90\%), acquisition mode (continuous), Pade-Laplace as analysis mode, Wallis resolution (medium), and Smoluchowski model as Henry function.

HT-29 and CaCo-2 colorectal adenocarcinoma cells were purchased from American Type culture Collection and cultured following the protocols described by the manufacturer. All the specific reagents for cell culture were acquired from ATCC and Sigma Aldrich [16]. The MTT assay was choose in order to verify the cell viability after stimulation with the samples (AuNPs, lupeol, lemon balm aqueous extract) and the methodology is described in previous studies $[17,18]$.

\section{Results and discussions}

Gold nanoparticles can be obtained by several methods, namely: (i) chemical synthesis - Turkevichfrens, Brust-Schiffrin and/or Martin methods; (ii) miscellaneous methods - sonolysis, and/ or Laser ablation; and (iii) biosynthesis/green methods - with microorganisms, biomolecules and/or plant extract [19]. Each method has its advantages and disadvantages but the ultimate goal is to obtain safe and biocompatible compounds for future uses in the pharmaceutical and medical fields.

In the present study, two different gold nanoparticles were obtained by chemical and biochemical synthesis respectively. The gold limit of detection was obtained at $0.0036 \mu \mathrm{g} / \mathrm{L}$ and gold concentration in AuNPs and Lup_AuNPs obtained by ICP-MS was 29.8374 and $24.1642 \mu \mathrm{g}$ Au/mL suspension. Gold nanoparticles obtained by chemical synthesis were loaded with lupeol to see activity following association with this bioactive molecule. The data are presented in Table 1 along with the data on size and stability.

Table 1. Characterization of gold nanoparticles:

i) chemical synthesized, ii) loaded with lupeol and iii) biosynthesized

\begin{tabular}{cccc}
\hline Sample & Conc $(\boldsymbol{\mu g ~ A u} / \mathbf{m L})$ & Size $(\mathbf{n m})$ & $\begin{array}{c}\text { Zeta potential } \\
(\mathbf{m V})\end{array}$ \\
\hline AuNPs & 29.486 & 38 & -31 \\
\hline Lup_AuNPs & 24.322 & 54 & -38 \\
\hline B_AuNPs & 31.485 & 82 & -27 \\
\hline
\end{tabular}


The MTT cell viability test was conducted in order to assess the viability of chemical and biochemical gold nanoparticles, gold nanoparticles loaded with lupeol, lupeol and lemon balm aqueous extract on HT-29 and CaCo-2 colon cancer cell lines.

The cells were stimulated with different concentrations of the test compounds at the $24 \mathrm{~h}$ time intervals. In the case of lupeol (Lup) and lupeol gold nanoparticles (Lup_AuNPs) the data showed that a slight cell viability decrease can be noticed at low concentrations for all the substances tested. In contrast, at high concentrations of Lup_AuNPs the viability in the case of HT-29 cells was around $76 \%$ (at $25 \mu \mathrm{M}$ ) and around $68 \%$ (at $50 \mu \mathrm{M}$ ) and in the case of CaCo-2 cells was around $85 \%$ (at 25 $\mu \mathrm{M})$ and around $78 \%$ (at $50 \mu \mathrm{M})$ as can be seen in Figure 2.

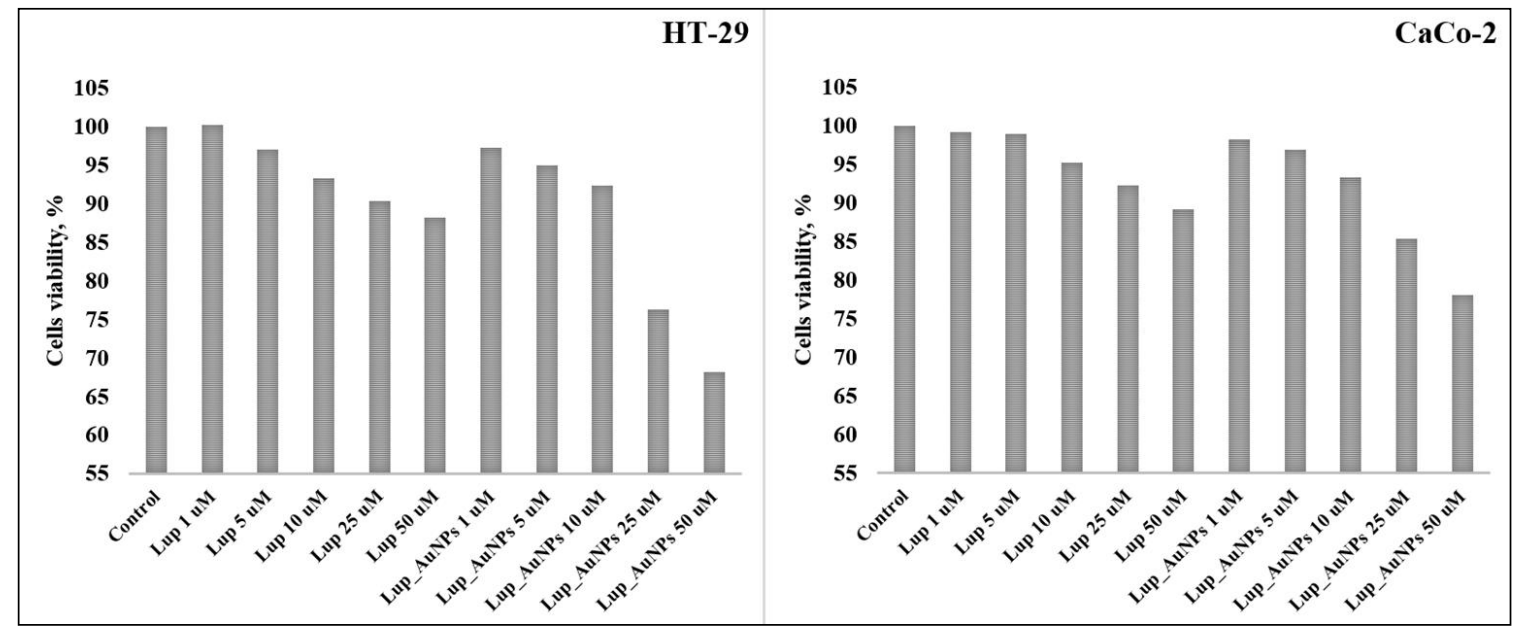

Figure 2. Viability of colorectal adenocarcinoma cells in the presence of lupeol and lupeol gold nanoparticles

In the case of testing other types of lupeol formulations, the MTT test did not show an abrupt reduction in cell viability and the treatments with it and PLGL showed differences: in the use of lupeol the viability was lower compared to PLGL nanoparticles [20].

Both lemon balm aqueous extract (LBE) and biosynthesized gold nanoparticles (B_AuNPs) were evaluated for cell viability. As shown in Figure 3, lemon balm extract at the concentrations tested (between $10-500 \mu \mathrm{g} / \mathrm{mL}$ ) does not show significant action on HT-29 or CaCo-2 cells viability. In the case of gold nanoparticles the viability values at high concentration tested were: $72 \%$ at $25 \mu \mathrm{M}, 59 \%$ at $50 \mu \mathrm{M}$ for HT-29 cells and $88 \%$ at $25 \mu \mathrm{M}, 71 \%$ at $50 \mu \mathrm{M}$ for CaCo-2 cells.

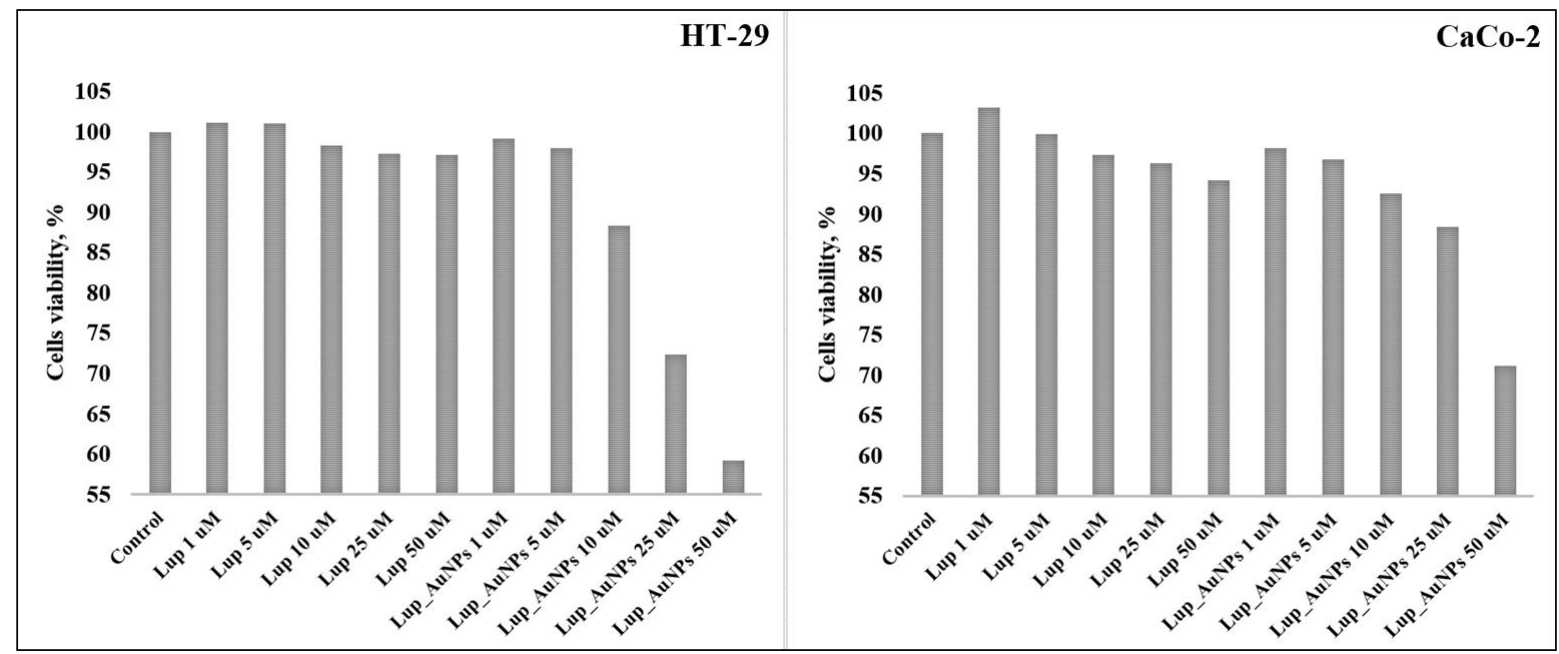

Figure 3. Viability of colorectal adenocarcinoma cells in the presence of lemon balm aqueous extract and biosynthesized gold nanoparticles 
Silver nanoparticles with proanthocyanidin have been synthesized and tested with promising results in colon cancer cells by Mani et al. [21]. Mata et al. have synthesized gold nanoparticles using Abutilon indicum leaf extract, which have a spherical shape and an average size of 1-20 nm and potential cytotoxic effects in the HT-29 human colon cancer cell line in vitro [22].

The cytotoxic effect of gold nanoparticles is presented in the literature on different cell lines but the data are different and the results are controversial. Regarding colon cells some authors reported noncytotoxic activity on $\mathrm{CaCo}-2$ cells and others to the contrary; particle size and concentration are important in terms of action. For example, sizes of gold nanoparticles, obtained by biosynthesis, between 1 and $20 \mathrm{~nm}$ led to IC50 values between 1066 and $914 \mu \mathrm{M}$, and commercial nanoparticles of varying sizes up to a maximum size of $15 \mathrm{~nm}$ led to IC50 values between 66 and $193 \mu \mathrm{M}$ (on HT-29 cells) [23]. In other similar studies, the cytotoxicity effect of gold nanoparticles synthesized and tested at concentrations of $50-500 \mu \mathrm{g} / \mathrm{ml}$ on HT-29 cells revealed a reduction in cell viability of up to $40 \%$ [24].

\section{Conclusions}

Gold nanoparticles obtained by both chemical synthesis and biosynthesis (using an aqueous extract of lemon balm) were studied. Their formation was confirmed by UV-Vis spectroscopy, their dimensions were in the range of 38-82 $\mathrm{nm}$ and the stability was good according to the values of the zeta potential. In order to evaluate the cytotoxic effect on colon adenocarcinoma cells, the association between metal nanoparticles and bioactive molecules was realized. Thus, the synthesized gold nanoparticles were loaded with lupeol and the biosynthesized gold nanoparticles were tested as such. More pronounced activity on colon cancer cells was observed in the case of lupeol loaded gold nanoparticles.

The increased pharmaceutical availability and the biocompatibility of the final products connected with the uniqueness of this research (there are just a few comparative studies on multiple gold-based nanoparticles used as drug delivery systems) are of great significance. These are the main reasons why the study must be continued and the clinical testing of these nanoparticles is imperative.

\section{References}

1. PAN, M.-H., GHAI, G., HO, C.-T., Food bioactives, apoptosis, and cancer, Mol. Nutr. Food Res., 52, 2008, 43-52.

2. CHATURVEDI, P.K., BHUI, K., SHUKLA, Y., Lupeol connotations for chemoprevention, Cancer Lett., 263, 2008, 1-13.

3. DALIBORCA, V.C., DUMITRASCU, V., POPESCU, R., CIMPORESCU, A., VLAD, C.S., FLANGEA, C., GRECU, D.S., VAGVOLGYI, C., PAPP, T., HORHAT, F., Gas Chromatography mass Spectrometry Evidences for New Chemical Insights of Momordica charantia, Rev. Chim., 66(11), 2015, 1914-1920.

4. HUANG, M., LU, J.-J., HUANG, M.-Q., BAO, J.-L., CHEN, X.-P., WANG, Y.-T., Terpenoids: natural products for cancer therapy, Expert Opin. Investig. Drugs, 21(12), 2012, 1801-1818.

5. KATZ, L., BALTZ, R.H., Natural product discovery: past, present, and future, J. Ind. Microbiol. Biotechnol., 43(2), 2016, 155-176.

6. SALEEM, M., Lupeol, a Novel Anti-Inflammatory and Anti-Cancer Dietary Triterpene, Cancer Lett., 285(2), 2009, 109-115.

7. AVIN, B.R.V., PRABHU, T., RAMESH, C.K., VIGNESHWARAN, V., RIAZ, M., JAYASHREE, K., PRABHAKAR., New role of lupeol in reticence of angiogenesis, the cellular parameter of neoplastic progression in tumorigenesis models through altered gene expression, Biochem. Biophys. Res. Commun., 448(2), 2014, 139-144.

8. LAGHARIA, A.H., MEMON, S., NELOFAR, A., KHAN, K.M., Alhagi maurorum: a convenient source of lupeol, Ind. Crops Prod., 34(1), 2011, 1141-1145.

9. MINDA, D., PAVEL, I.Z., BORCAN, F., CORICOVAC, D., PINZARU, I., ANDRICA, F., 
MORGOVAN, C., NITA, L.D., SOICA, C., MUNTEAN, D., TOMA, C.C., Benficial Effects of a Lupeol-Cyclodextrin Complex in a Murine Model of Photochemical Skin Carcinoma, Rev. Chim., 66(3), 2015, 373-377.

10. HEGHES, A., ȘOICA, C.M., ARDELEAN, S., AMBRUS, R., MUNTEAN, D., GĂLUȘCAN, A., DRAGOS,, D., IONESCU, D., BORCAN, F., Influence of emulsifiers on the characteristics of polyurethane structures used as drug carrier. Chem. Cent. J., 7(1), 2013, 66.

11. DANCIU, C., BORCAN, F., ȘOICA, C., ZUPKO, I., CSANYI, E., AMBRUS, R., MUNTEAN, D., SASS, C., ANTAL, D., TOMA, C., DEHELEAN, C., Polyurethane Microstructures-a Good or Bad in vitro Partner for the Isoflavone Genistein? Nat. Prod. Comm., 10(6), 2015, 951-954.

12. BACIU, S., BERECE, C., FlOREA, A., BURDE, A.V., MUNTEANU, A., ANDOR CIGU, T., HOSSZU, T., SZUHANEK, C., MANOLE, M., SINESCU, C., Three-dimensional Marginal Evaluation of Two Pressed Materials Using Micro-CT Technology, Rev. Chim., 68(3), 2017, 615-618.

13. ROSIANU, R.S., PODARIU, A.C., MATEI, C., TAMPA, M., OANCEA, R., Investigation of a Hydroxyapatite/tri-calcium-phosphate Scaffold as Carrier for Mesenchymal Stem Cells in Alveolar Bone Regeneration, Rev. Chim., 65(9), 2014, 1049-1051.

14. ZHANG, X., Gold nanoparticles: Recent advances in the biomedical applications, Cell Biochem. Biophys., 72, 2015, 771-775.

15. TURKEVICH, J., STEVENSON, P.C., HILlIER, J., A study of the nucleation and growth processes in the synthesis of colloidal gold, Faraday Soc., 11, 1951, 55.

16. ATCC. Available online: www.atcc.org (accessed on 18 Febr 2020).

17. ISAIA (OARCEA), A.I., IENASCU, I.M.C., ANDRICA, F.M., GEORGESCU, D., BRATOSIN, D., PINZARU, I.A., Preliminary in vitro Evaluation of Seven Different Plant Extracts on A375, B164A5 and HaCat Cell Lines, Rev. Chim., 67(8), 2016, 1633-1636.

18. ANDOR, B., TISCHER (TUCUINA), A.A., BERCEANU-VADUVA, D., LAZUREANU, V., CHEVERESAN, A., POENARU, M., Antimicrobial Activity and Cytotoxic Effect on Gingival Cells of Silver Nanoparticles Obtained by Biosynthesis, Rev. Chim. (Bucharest), 70(3), 2019, 781-783.

19. TEIMOURI, M., KHOSRAVI-NEJAD, F., ATTAR, F., SABOURY, A.A., KOSTOVA, I., BENELLI, G., FALAHATI, M., Gold nanoparticles fabrication by plant extracts: synthesis, characterization, degradation of 4-nitrophenol from industrial wastewater, and insecticidal activity - a review, J. Clean Prod., 184, 2018, 740-753.

20. CHÁIREZ-RAMÍREZ, M.H., SÁNCHEZ-BURGOS, J.A., GOMES, C., MORENO-JIMÉNEZ, M.R., GONZÁLEZ-LAREDO, R.F., BERNAD-BERNAD, M.J., MEDINA-TORRES, L., RAMÍREZMARES, M.V., GALLEGOS-INFANTE, J.A., ROCHA-GUZMÁN, N.E., Morphological and release characterization of nanoparticles formulated with poly (dl-lactide-co-glycolide) (PLGA) and lupeol: In vitro permeability and modulator effect on NF- $\mathrm{BB}$ in Caco-2 cell system stimulated with TNF- $\alpha$, Food Chem Toxicol., 85, 2015, 2-9.

21. MANI, S., BALASUBRAMANIAN, M.G., PONNUSAMY, P., VIJAYAN, P., Antineoplastic effect of PAC capped silver nanoparticles promote apoptosis in HT-29 human colon cancer cells, $J$. Clust. Sci., 30, 2019, 483-493.

22. MATA, R., NAKKALA, J.R., SADRAS, S.R., Polyphenol stabilized colloidal gold nanoparticles from Abutilon indicum leaf extract induce apoptosis in HT-29 colon cancer cells, Coll. Surf. B Biointerfaces, 143, 2016, 499-510.

23. GONZÁLEZ-BALLESTEROS, N., PRADO-LÓPEZ, S., RODRÍGUEZ-GONZÁLEZ, J.B., LASTRA, M., RODRÍGUEZ-ARGÜELLES, M.C. Green synthesis of gold nanoparticles using brown algae Cystoseira baccata: Its activity in colon cancer cells, Coll. Surf. B Biointerfaces., 153, 2017, 190198.

24.MIRI, A., DARROUDI, M., ENTEZARI, R., SARANI, M., Biosynthesis of gold nanoparticles using Prosopis farcta extract and its in vitro toxicity on colon cancer cells, Res. Chem. Intermed., 44, 2018, 31693177 .

$\overline{\text { Manuscript received: } 10.02 .2020}$ 